\title{
The Tarama Knoll: Geochemical and Biological Profiles of Hydrothermal Activity
}

\author{
Toshiro Yamanaka, Hiromi Nagashio, Ryu Nishio, Kazuna Kondo, Takuroh \\ Noguchi, Kei Okamura, Takuro Nunoura, Hiroko Makita, Kentaro Nakamura, \\ Hiromi Watanabe, Kazuhiro Inoue, Tomohiro Toki, Kouichiro Iguchi, Urumu \\ Tsunogai, Ryoichi Nakada, Shogo Ohshima, Shin Toyoda, Jun Kawai, \\ Naohiro Yoshida, Akira ljiri, and Michinari Sunamura
}

\begin{abstract}
Tarama Knoll is located about $60 \mathrm{~km}$ north of Tarama Island, Sakishima Islands, southwestern Japan. The knoll has an almost conical shape, with foot and summit depths of 2,000 and $1,490 \mathrm{~m}$ (total relief $=510 \mathrm{~m}$ ) from the sea surface, respectively. This area has been identified as a possible active submerged volcano called "Tarama Knoll" (Otani et al. 2004). However, there are actually two separate knolls in the area. This knoll is located northeast of the other, which is named Tarama Hill. During the KT05-26 cruise on the R/V
\end{abstract}

T. Yamanaka $(\bowtie) \bullet H$. Nagashio $\bullet$ R. Nishio $\bullet$ K. Kondo Graduate School of Natural Science and Technology, Okayama University, 1-1, Naka-3-chome Kita-ku, Okayama 700-8530, Japan e-mail: toshiroy@cc.okayama-u.ac.jp

\section{T. Noguchi}

Center for Advanced Marine Core Research, Kochi University, B200 Monobe, Nankoku, Kochi 783-8502, Japan

Marine Technology and Engineering Center, Japan Agency for Marine-Earth Science and Technology,

2-15 Natsushima-cho, Yokosuka, Kanagawa 237-0061, Japan

K. Okamura

Center for Advanced Marine Core Research, Kochi University, B200 Monobe, Nankoku, Kochi 783-8502, Japan

\section{T. Nunoura}

Subsurface Geobiology Advanced Research (SUGAR) Project, Japan Agency for Marine-Earth Science and Technology (JAMSTEC), 2-15 Natsushima-cho, Yokosuka 237-0061, Japan

Marine Functional Biology Group, Research and Development (R\&D) Center for Marine Biosciences, Japan Agency for Marine-Earth Science \& Technology, 2-15 Natsushima-cho, Yokosuka 237-0061, Japan

H. Makita

Subsurface Geobiology Advanced Research (SUGAR) Project, Japan Agency for Marine-Earth Science and Technology (JAMSTEC), 2-15 Natsushima-cho, Yokosuka 237-0061, Japan

\section{K. Nakamura}

Precambrian Ecosystem Laboratory (PEL), Japan Agency for Marine-Earth Science and Technology (JAMSTEC), 2-15 Natsushima-cho, Yokosuka 237-0061, Japan

Department of Systems Innovation, School of Engineering, The University of Tokyo, 7-3-1 Hongo, Bunkyo-ku, Tokyo 113-8656, Japan

H. Watanabe

Department of Marine Biodiversity Research, Japan Agency for Marine-Earth Science and Technology (JAMSTEC), 2-15 Natsushima-cho, Yokosuka 237-0061, Japan

K. Inoue $\bullet$ N. Yoshida Deptartment of Environmental Chemistry \& Engineering, Department of Environmental Science \& Technology, The Research Center for the Evolving Earth \& Planets, Tokyo Institute of Technology G1-17, 4259 Nagatsuta, Midori-ku, Yokohama 226-8502, Japan

T. Toki

Faculty of Science, University of the Ryukyus, 1 Senbaru, Nishihara, Okinawa 903-0213, Japan

K. Iguchi

Faculty of Science, Hokkaido University, Kita-10 Nishi-8 Kita-ku, Sapporo 060-0810, Japan

U. Tsunogai

Faculty of Science, Hokkaido University, Kita-10 Nishi-8 Kita-ku, Sapporo 060-0810, Japan

Graduate School of Environmental Studies, Nagoya University, Furo-cho, Chikusa-ku, Nagoya 464-8601, Japan

R. Nakada

Graduate School of Science, Hiroshima University, Higashi-Hiroshima, Hiroshima 739-8526, Japan

Earth-Life Science Institute, Tokyo Institute of Technology, 2-12-1 Ookayama, Meguro, Tokyo 152-8550, Japan

S. Ohshima

Graduate School of Science, Kyushu University, 6-10-1, Hakozaki, Higashi-ku, Fukuoka 812-8581, Japan 
Tanseimaru, a methane anomaly was detected near the seafloor around the area and was considered to be of possible hydrothermal origin. Based on visual observation of the seafloor and its bathymetry, this knoll is considered a pumice cone. Dense turbid water is often observed around summit of the knoll, and a methane anomaly was detected in the water. These observations suggest that the turbid water is a hydrothermal plume. An ironrich, red-brown sediment-covered area was discovered at a depth of $1,510-1,540 \mathrm{~m}$ on the southwestern slope near the summit. At the red-brown sediment area, a weak shimmering of clear fluid could be observed, and the fluid temperature reached $20{ }^{\circ} \mathrm{C}$. Sampled shimmering fluid showed a high silica concentration $(\geq 1 \mathrm{mM})$, indicating an interaction between the fluid and the surrounding rock. These chemical data support the occurrence of active hydrothermal circulation at Tarama Knoll.

Keywords

Hydrothermal activity • Hydrothermal plume • Southern Okinawa Trough • Tarama Knoll

\subsection{Location and Bathymetric Features of Tarama Knoll}

Tarama Knoll is located at $25^{\circ} 05.50^{\prime} \mathrm{N}, 124^{\circ} 32.50^{\prime} \mathrm{E}$ (Fig. 40.1). The knoll lies almost at the foot of the south fault scarp in the rift graben of the southern Okinawa Trough (Letouzey and Kimura 1986). The knoll has an almost conical shape and an additional small peak on the northern slope
(Fig. 40.2). The depths of the main summit and foot are 1,490 and about $2,000 \mathrm{~m}$ from the sea surface, respectively, and the total relief from the foot to summit is $510 \mathrm{~m}$. The average steepness is $c .18^{\circ}$, and the steepness does not change significantly from the foot to the summit. Another smaller knoll named Tarama Hill is located about $4 \mathrm{~km}$ southwest of Tarama Knoll.

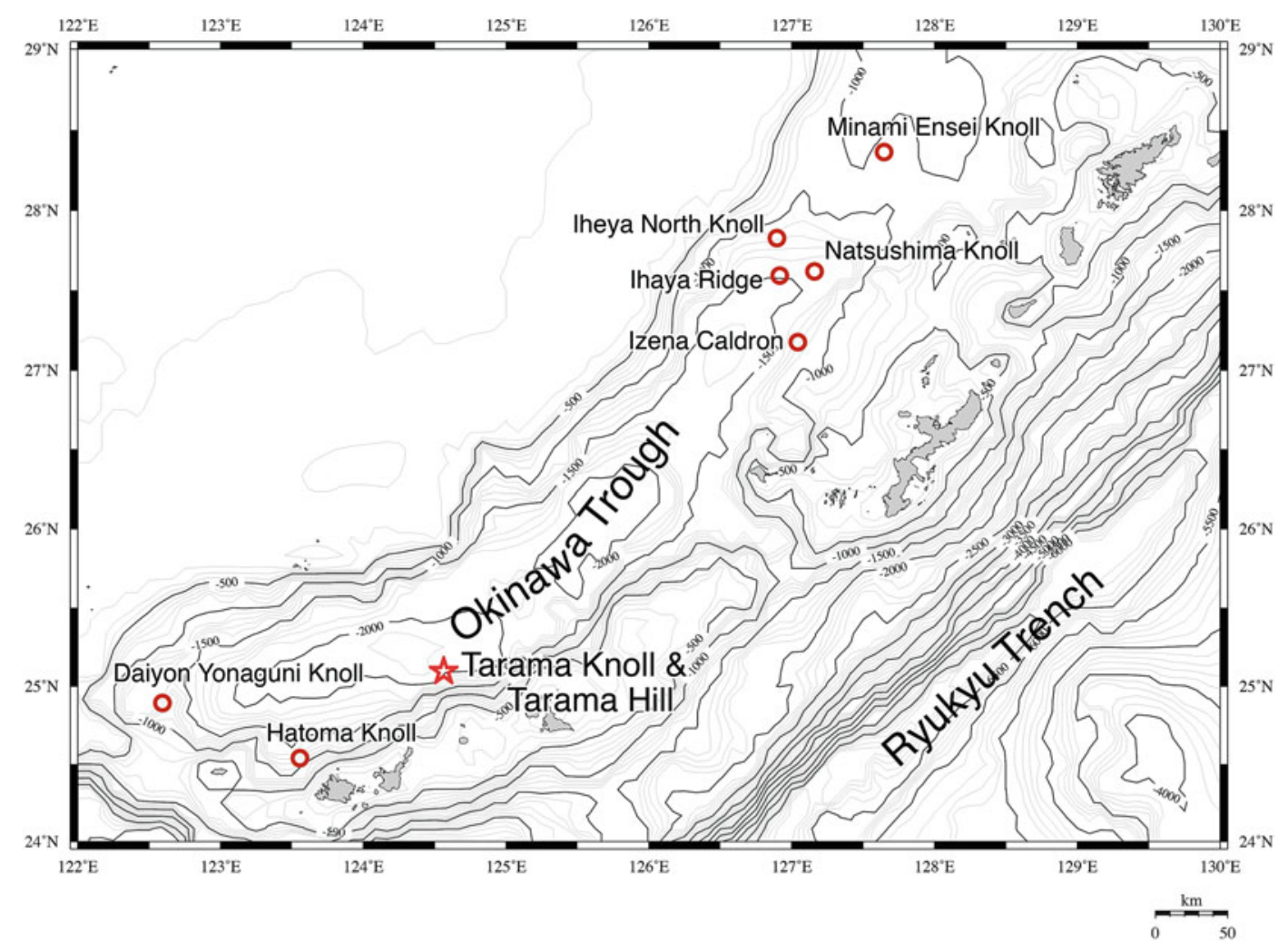

Fig. 40.1 Locations of Tarama Knoll and Tarama Hill and other hydrothermal fields in the Okinawa Trough 
Fig. 40.2 Bathymetric map of Tarama Knoll and Tarama Hill obtained by the SeaBat 8160 multibeam echosounder on the R/V Natsushima during NT09-10 Leg. 2 and NT10-06 Leg. 2 cruises. The $\mathrm{X}$ indicates the sampling point during the KT0526 cruise
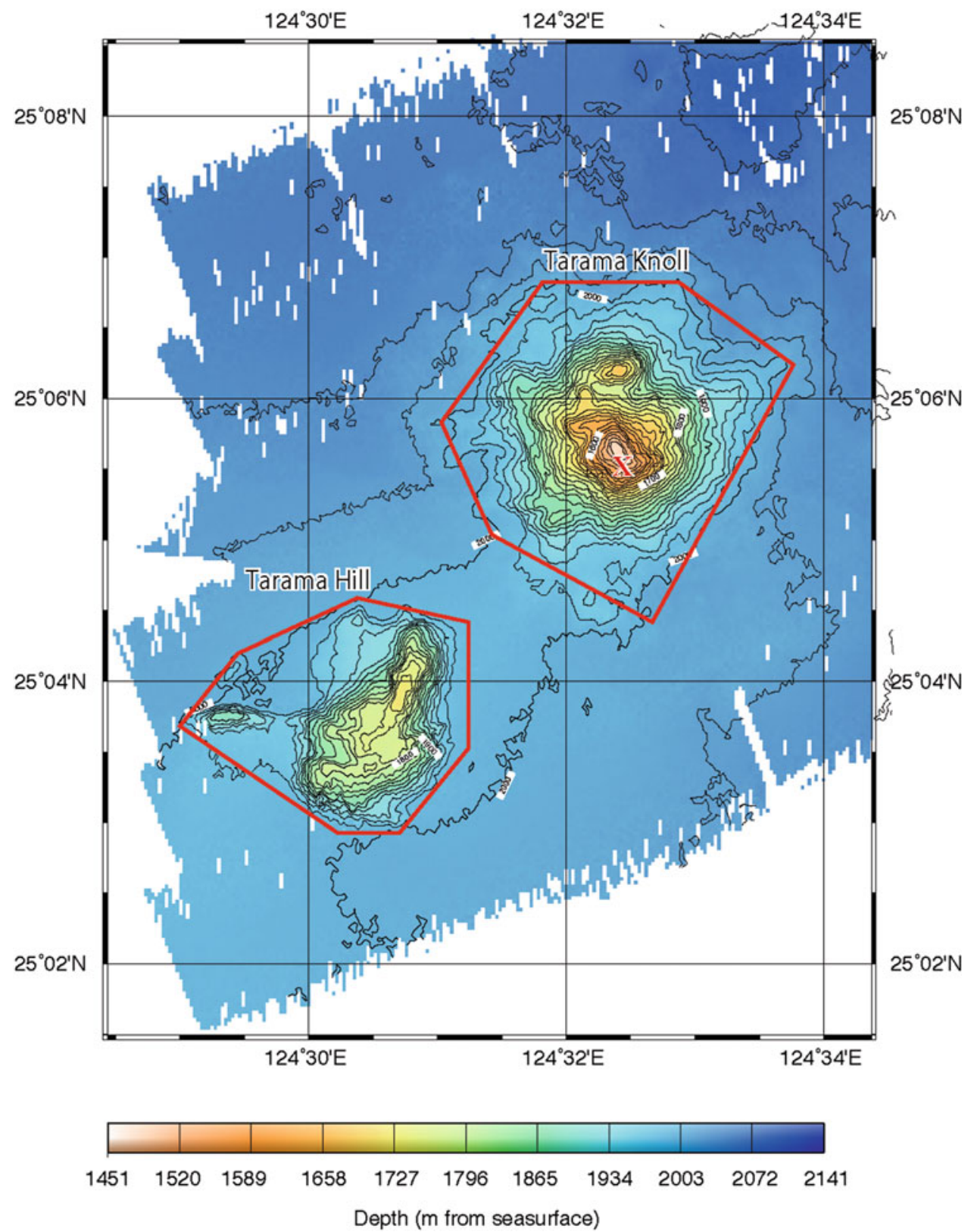

\subsection{Observation History of Tarama Knoll}

Tarama Knoll was originally described as a single-summit active volcano based on low-resolution seismic and geomagnetic observations carried by the Hydrographic Surveys Division of Japan Coast Guard (Otani et al. 2004). Tarama Knoll and Tarama Hill were then identified as one elongated knoll due to insufficient resolution (Fig. 40.2). This area was visited by the R/V Tanseimaru during the KT05-26 cruise, and a methane anomaly was detected near the seafloor that was considered of possible hydrothermal origin (Fig. 40.3). During the NT09-10 Leg. 2 cruise in 2009, a high-resolution seismic survey was done by the R/V Natsushima (which belongs to JAMSTEC) using a SeaBat 8160 multibeam echosounder, and the results showed two independent knolls. A methane anomaly was detected near the Tarama Knoll, and therefore dive surveys using the ROV/ HyperDolphin were carried out at the knoll in 2009, 2010, and 2011.

\subsection{Dive Observations at Tarama Knoll}

Since 2009, we have done seven dives using the ROV/ HyperDolphin (which belongs to JAMSTEC) at the Tarama Knoll (Table 40.1). All dive tracks are shown in Fig. 40.4. During the dives, we often observed dense turbid water 


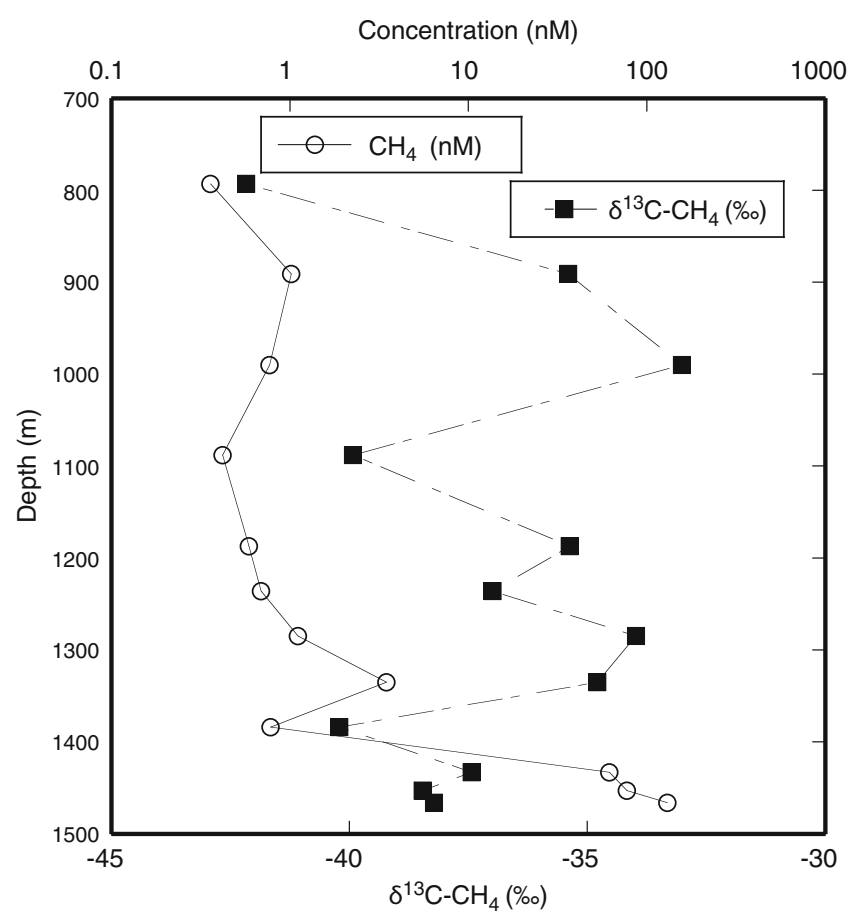

Fig. 40.3 Vertical profiles of the methane concentrations and $\delta^{13} \mathrm{C}$ values of methane dissolved in seawater. Samples were obtained during the KT05-26 cruise

resembling hydrothermal plumes, and many planktonic tunicates were observed in the water. As such planktonic tunicates have often been observed in hydrothermal plumes emitted by active hydrothermal vents in the Okinawa Trough (Miyake et al. 2009), hydrothermal venting from a nearby area was expected. However, no active venting site has yet been found. Visual observation of the seafloor indicated rubble and angular gravel covering the slope (Fig. 40.5a). Although benthic animals were rarely found on the slope, dense sponge colonies were found in the area where dense turbid water covered the seafloor (Fig. 40.5b).

Weak shimmering of clear warm fluid (up to $23^{\circ} \mathrm{C}$ ) was found on the southwestern slope near the summit at a depth of 1,510-1,540 $\mathrm{m}$ in an area covered with red-brown sediment. Many finger-like chimneys consisting of the redbrown sediment were observed in this area (Fig. 40.5c, d), which was named the "Fox site" (Makita et al., in prep.). The shimmering fluid was sampled.

\subsection{Fluid, Rock, and Sediment Chemistry}

Turbid water, shimmering fluid, rocks, and red-brown sediments were sampled during dive studies and subjected to chemical analyses. The results of the analyses are summarized in Tables 40.1 and 40.2. Analysis of the turbid water showed that the concentrations of major cations (sodium, magnesium, calcium, and potassium) and anions (chloride and sulfate) were similar to those in ambient seawater, but the methane concentration in the turbid water was one or two orders of magnitude higher than that of the ambient seawater (Table 40.1). These observations suggest that the turbid water may be from a hydrothermal plume. The shimmering fluid showed high concentrations of silica, ammonium, and alkalinity relative to seawater, whereas concentrations of magnesium, sodium, and potassium were slightly lower than those of the ambient seawater. Although the data are insufficient for accurate hydrothermal endmember estimation, the estimated endmember concentration of silica reached around $11 \mathrm{mM}$. The endmember silica concentration corresponds to a reservoir temperature of $260{ }^{\circ} \mathrm{C}$ based on the silica geothermometer, assuming equilibrium with quartz (Fournier 1977). The chemical signature enriched in ammonium, methane, and alkalinity suggests interaction with sedimentary organic matter during hydrothermal circulation, similar to other hydrothermal fluids in the Okinawa Trough (Ishibashi and Urabe 1995). The decreased levels of major cations in the fluid may suggest phase separation or segregation in the subseafloor. Hydrogen sulfide was not detected in the fluid.

Most sampled rocks seemed to be pumice and lava fragments based on their visual texture and whitish color (Fig. 40.6). Bulk chemical composition of one lava fragment sample collected during HyperDolphin dive \#1109 (Table 40.2) showed a high silica content $(>75 \%)$ suggestive of rhyolitic magma activity.

The red-brown sediment was rich in iron oxide and was composed mainly of ferrihydrite or possibly microcrystalline goethite (Makita et al., in prep.).

\subsection{Biological Observation}

Some animal samples were collected during the dive studies, and details were reported by Yamanaka et al. (Chap. 10). Although typical vent endemic species, such as vesicomyid clams, mytilid mussels, and vestimentiferan tubeworms, were not found during the dive studies, one liparid snailfish specimen (Fig. 40.7) obtained during HyperDolphin dive \#1322 contained remains of undigested Alvinocaris shrimp and shell of Provanna snail in its gut. These shrimp and snail species are endemic to hydrothermal vents and methane seeps (e.g., Fujikura et al. 2012) and represent feed of snailfish in hydrothermal vent areas (Takemura et al. 2010). The migrating ability of liparid snailfish is not known, and the possible habitat area may be less than several kilometers square. Isotopic signatures obtained from the sponges had significantly low $\delta^{34} \mathrm{~S}$ values (about +2.5 to $+5.0 \%$ ), indicating that they rely on thioautotrophic products (e.g., sulfur-oxidizing bacteria) that utilize reduced sulfur 
Table 40.1 Results of chemical analyses of seawater and shimmering fluid obtained from Tarama Knoll

\begin{tabular}{|c|c|c|c|c|c|c|c|c|c|c|c|c|c|c|c|c|c|}
\hline Date & $\begin{array}{l}\text { HPD } \\
\text { Dive } \\
\text { No. }\end{array}$ & $\mathrm{ID}^{\mathrm{a}}$ & $\begin{array}{l}\mathrm{Mg} \\
(\mathrm{mM})\end{array}$ & $\begin{array}{l}\mathrm{Ca} \\
(\mathrm{mM})\end{array}$ & $\begin{array}{l}\mathrm{Na} \\
(\mathrm{mM})\end{array}$ & $\mathrm{K}$ & $\begin{array}{l}\mathrm{SO}_{4} \\
(\mathrm{mM})\end{array}$ & $\begin{array}{l}\mathrm{Cl} \\
(\mathrm{mM})\end{array}$ & $\begin{array}{l}\mathrm{Fe} \\
(\mu \mathrm{M})\end{array}$ & $\begin{array}{l}\mathrm{Si} \\
(\mu \mathrm{M})\end{array}$ & $\begin{array}{l}\mathrm{NH}_{4} \\
(\mu \mathrm{M})\end{array}$ & $\mathrm{pH}$ & $\begin{array}{l}\text { alk. } \\
(\mathrm{mM})\end{array}$ & $\begin{array}{l}\mathrm{CH}_{4} \\
(\mathrm{nM})\end{array}$ & $\begin{array}{l}\delta^{13} \mathrm{C}- \\
\mathrm{CH}_{4} \\
(\%)\end{array}$ & $\begin{array}{l}\delta \mathrm{D}- \\
\mathrm{CH}_{4} \\
(\% \circ)\end{array}$ & Note \\
\hline \multirow[t]{2}{*}{2009.7 .20} & 1032 & N1 & 53.1 & 10.3 & 472.5 & 9.1 & 27.4 & 539.3 & na. & 124.0 & 3.0 & 7.72 & 2.56 & 30.3 & -35.4 & na. & Turbid water \\
\hline & & $\mathrm{N} 2$ & 53.8 & 10.4 & 471.6 & 10.0 & 27.7 & 540.4 & na. & 124.0 & 2.0 & 7.81 & 2.34 & 16.4 & -34.9 & na. & Turbid water \\
\hline \multirow[t]{2}{*}{ 2009.7.21 } & 1033 & N1 & 52.2 & 10.3 & 474.1 & 10.3 & 27.3 & 540.4 & na. & 123.0 & nd. & 7.72 & 2.50 & 2.07 & -43.1 & na. & $\begin{array}{l}\text { Ambient } \\
\text { seawater }\end{array}$ \\
\hline & & $\mathrm{N} 2$ & 52.0 & 10.3 & 465.5 & 10.0 & 27.4 & 535.9 & na. & 123.0 & 1.0 & 7.64 & 2.35 & 45.2 & -33.4 & na. & Turbid water \\
\hline \multirow[t]{5}{*}{2009.7 .22} & 1034 & N1 & 52.5 & 10.3 & 472.4 & 10.2 & 27.4 & 539.3 & na. & 126.5 & 6.9 & 7.75 & 2.37 & 654 & -39.1 & -105 & Turbid water \\
\hline & & N2 & 53.8 & 8.4 & 480.2 & 10.3 & 29.0 & 538.2 & na. & 123.7 & 8.0 & 7.77 & 2.42 & 52.7 & -36.5 & -132 & Turbid water \\
\hline & & $\mathrm{V}$ & 48.5 & 9.7 & 435.0 & 9.5 & na. & na. & na. & na. & na. & na. & na. & 2,320 & -35.9 & -143 & $\begin{array}{l}\text { Shimmering } \\
\text { fluid }\end{array}$ \\
\hline & & B & 50.0 & 10.0 & 452.0 & 9.6 & 27.7 & 538.2 & na. & 128.4 & 10.8 & 7.80 & 2.51 & na. & na. & na. & $\begin{array}{l}\text { Shimmering } \\
\text { fluid }\end{array}$ \\
\hline & & $\mathrm{M}$ & 52.0 & 10.7 & 474.9 & 9.0 & 30.8 & 539.3 & 52.9 & 314.5 & 38.8 & 7.57 & 3.15 & na. & na. & na. & $\begin{array}{l}\text { Shimmering } \\
\text { fluid }\end{array}$ \\
\hline \multirow[t]{2}{*}{2010.4 .9} & 1107 & $\mathrm{~N}$ & 53.0 & 10.5 & 471.3 & 10.1 & 28.3 & 522.9 & na. & 131.2 & 1.2 & na. & na. & na. & na. & na. & Turbid water \\
\hline & & $\mathrm{M}$ & 53.4 & 10.5 & 474.5 & 10.2 & 28.9 & 531.4 & na. & 131.3 & 1.8 & na. & na. & na. & na. & na. & $\begin{array}{l}\text { Shimmering } \\
\text { fluid }\end{array}$ \\
\hline \multirow[t]{3}{*}{2010.4 .10} & 1108 & N1 & 53.1 & 10.5 & 472.3 & 10.1 & 21.7 & 433.4 & na & 123.0 & 1.8 & na. & na. & na. & na. & na. & Turbid water \\
\hline & & $\mathrm{N} 2$ & 53.3 & 10.5 & 473.1 & 10.1 & 28.5 & 526.4 & na. & 124.2 & 1.8 & na. & na. & na. & na. & na. & Turbid water \\
\hline & & BW1 & 47.9 & 10.5 & 439.9 & 10.3 & 27.0 & 526.5 & na. & 562.9 & 78.8 & na. & na. & na. & na. & na. & $\begin{array}{l}\text { Shimmering } \\
\text { fluid }\end{array}$ \\
\hline \multirow[t]{10}{*}{2010.4 .11} & 1109 & $\mathrm{~N} 1$ & 53.6 & 10.6 & 477.2 & 10.2 & 29.1 & 533.8 & na. & 121.3 & 0.5 & na. & na. & na. & na. & na. & Turbid water \\
\hline & & $\mathrm{N} 2$ & 53.5 & 10.6 & 476.6 & 10.2 & 28.8 & 529.9 & na. & 121.5 & 1.0 & na. & na. & na. & na. & na. & Turbid water \\
\hline & & $\mathrm{N} 3$ & 53.6 & 10.6 & 476.6 & 10.2 & 28.6 & 527.9 & na. & 122.0 & 1.2 & na. & na. & na. & na. & na. & Turbid water \\
\hline & & W1 & 48.6 & 12.1 & 463.5 & 11.6 & na. & na. & na. & na. & na. & na. & na. & na. & na. & na. & $\begin{array}{l}\text { Shimmering } \\
\text { fluid }\end{array}$ \\
\hline & & W2 & 50.0 & 11.1 & 461.1 & 10.8 & 25.8 & 523.9 & 0.078 & 662.9 & 59.5 & na. & na. & na. & na. & na. & $\begin{array}{l}\text { Shimmering } \\
\text { fluid }\end{array}$ \\
\hline & & W3 & 50.7 & 12.6 & 483.0 & 12.1 & na. & na. & na. & na. & na. & na. & na. & na. & na. & na. & $\begin{array}{l}\text { Shimmering } \\
\text { fluid }\end{array}$ \\
\hline & & W4 & 48.8 & 12.0 & 463.7 & 11.6 & 25.6 & 523.2 & 0.14 & 1,030 & 98.2 & na. & na. & na. & na. & na. & $\begin{array}{l}\text { Shimmering } \\
\text { fluid }\end{array}$ \\
\hline & & B & 48.2 & 11.6 & 454.5 & 11.2 & 25.6 & 522.4 & na. & 891.7 & 88.2 & na. & na. & na. & na. & na. & $\begin{array}{l}\text { Shimmering } \\
\text { fluid }\end{array}$ \\
\hline & & EW1 & 49.4 & 12.0 & 467.6 & 11.6 & 26.5 & 522.1 & 0.109 & 948.8 & 95.8 & na. & na. & na. & na. & na. & $\begin{array}{l}\text { Shimmering } \\
\text { fluid }\end{array}$ \\
\hline & & EW2 & 50.0 & 12.1 & 473.1 & 11.7 & 25.1 & 519.1 & 0.082 & 891.7 & 93.2 & na. & na. & na. & na. & na. & $\begin{array}{l}\text { Shimmering } \\
\text { fluid }\end{array}$ \\
\hline \multirow[t]{8}{*}{2011.9 .15} & 1322 & W1 & 45.8 & 11.7 & 465.1 & 11.8 & 26.4 & 539.6 & na. & 1,045 & 94.3 & 6.39 & 6.84 & na. & na. & na. & $\begin{array}{l}\text { Shimmering } \\
\text { fluid }\end{array}$ \\
\hline & & W2 & na. & na. & na. & na. & na. & na. & na. & na. & na. & na. & na. & 5,170 & na. & na. & $\begin{array}{l}\text { Shimmering } \\
\text { fluid }\end{array}$ \\
\hline & & W3 & 51.2 & 9.5 & 462.9 & 10.1 & 27.7 & 556.0 & na. & 198.5 & 10.1 & 6.94 & 2.69 & na. & na. & na. & $\begin{array}{l}\text { Shimmering } \\
\text { fluid }\end{array}$ \\
\hline & & W4 & na. & na. & na. & na. & na. & na. & na. & na. & na. & na. & na. & 2,750 & na. & na. & $\begin{array}{l}\text { Shimmering } \\
\text { fluid }\end{array}$ \\
\hline & & $\mathrm{CW} 2$ & 50.8 & 9.9 & 468.2 & 10.4 & 27.7 & 546.5 & na. & 204.3 & 12.1 & 6.80 & 2.78 & 11,800 & na. & na. & $\begin{array}{l}\text { Shimmering } \\
\text { fluid }\end{array}$ \\
\hline & & B & na. & na. & na. & na. & na. & na. & na. & na. & na. & 6.92 & na. & na. & na. & na. & $\begin{array}{l}\text { Shimmering } \\
\text { fluid }\end{array}$ \\
\hline & & N1 & 51.5 & 9.8 & 469.3 & 10.4 & 27.8 & 544.9 & na. & 113.0 & 3.2 & 7.69 & 2.40 & na. & na. & na. & Turbid water \\
\hline & & $\mathrm{N} 2$ & 51.5 & 10.4 & 468.4 & 10.3 & 28.0 & 547.3 & na. & 110.7 & 2.4 & 7.65 & 2.42 & na. & na. & na. & Turbid water \\
\hline
\end{tabular}

${ }^{a}$ Alphabets indicate sampler type, $N$ Niskin bottole, $V$ Vacumed metal bottle, $B$ Plastic bag, $M$ M-type sediment sampler, $W, B E, C W$ and $E W$ WHATS fluid sampler 


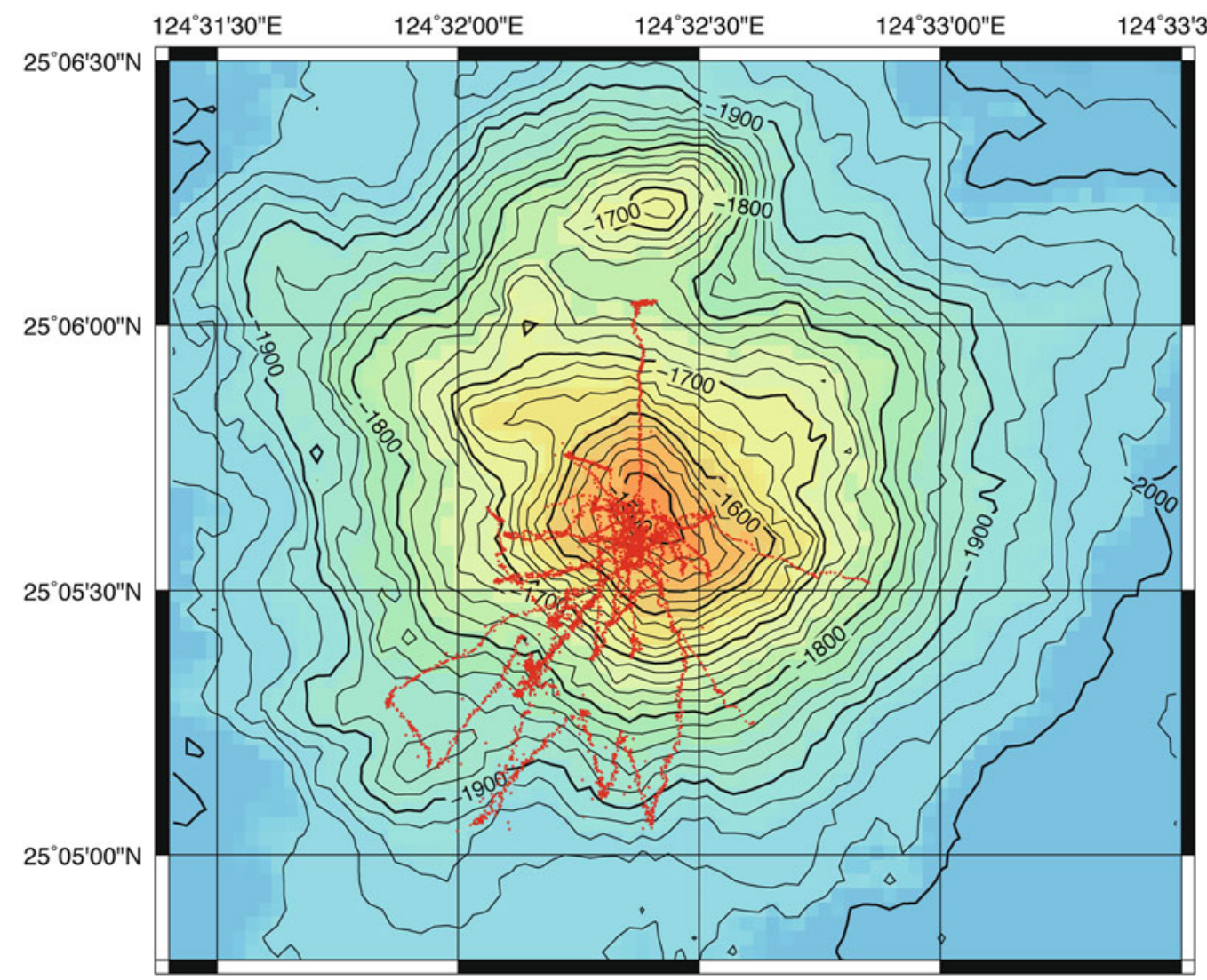

Fig. 40.4 Dive tracks of ROV/HyperDolphin surveys of this area are shown as red dotted lines. Seven dives (Dive Nos. 1032-1034, $1107-1108,1132)$ were done
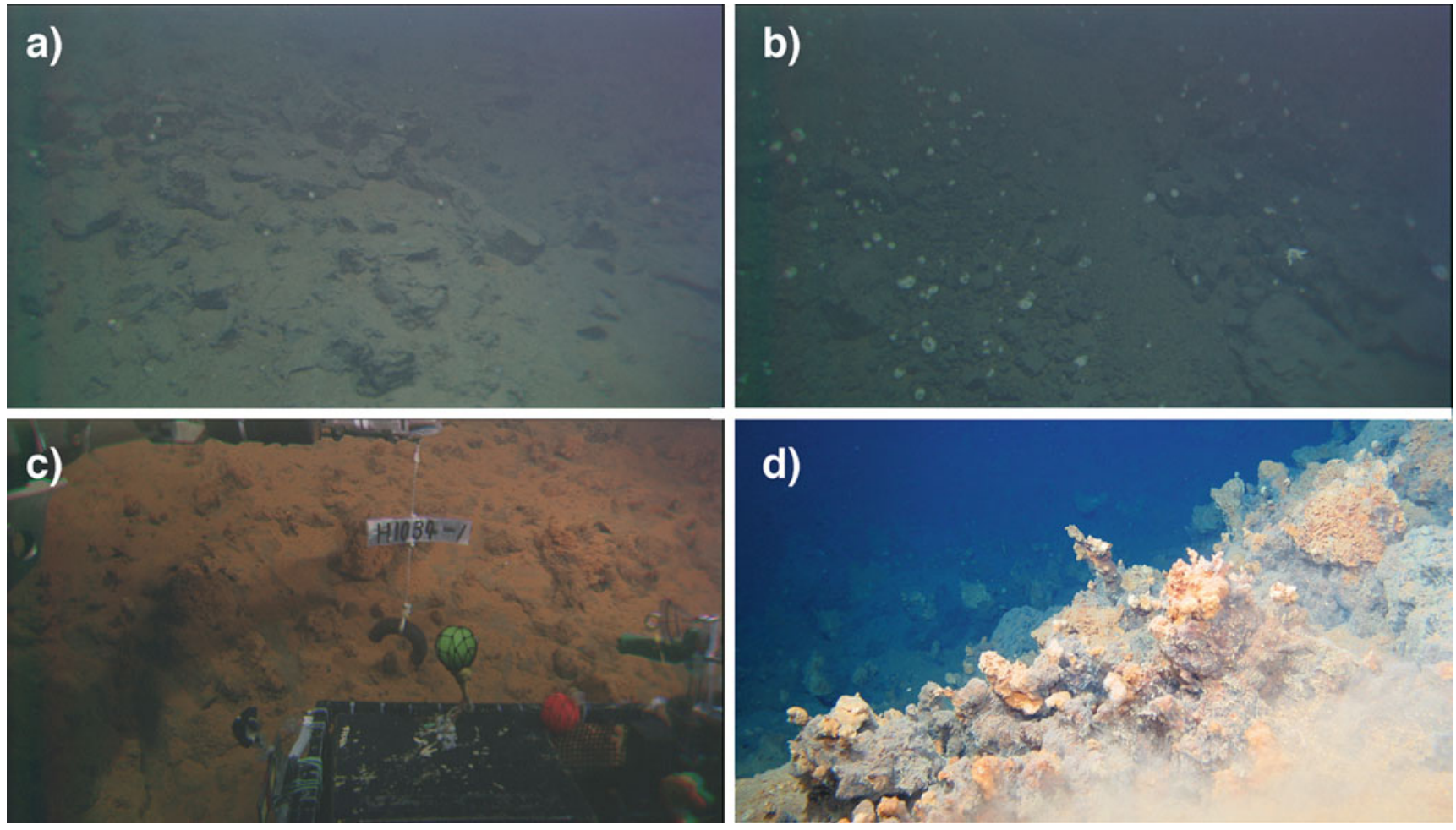

Fig. 40.5 Photographs of the seafloor on the slope of Tarama Knoll. (a) Rubble and angular gravel covered the slope. (b) Dense sponge colonies were observed in some areas on the slope. (c) Red-brown

sediment widely covered the southwestern slope near the summit. (d) Many "finger" chimneys were found 
Table 40.2 Bulk chemical composition of a rock sample obtained from Tarama Knoll

\begin{tabular}{|c|c|c|c|c|c|c|c|c|c|c|c|c|c|c|c|}
\hline \multirow[b]{2}{*}{ Sample No. } & \multicolumn{15}{|c|}{ Sampling point } \\
\hline & Latitude & Longitude & $\begin{array}{l}\text { Depth } \\
\text { (m) }\end{array}$ & $\begin{array}{l}\mathrm{SiO}_{2} \\
(\%)\end{array}$ & $\begin{array}{l}\mathrm{Al}_{2} \mathrm{O}_{3} \\
(\%)\end{array}$ & $\begin{array}{l}\mathrm{Fe}_{2} \mathrm{O}_{3}(\mathrm{~T}) \\
(\%)\end{array}$ & $\begin{array}{l}\mathrm{MnO} \\
(\%)\end{array}$ & $\begin{array}{l}\mathrm{MgO} \\
(\%)\end{array}$ & $\begin{array}{l}\mathrm{CaO} \\
(\%)\end{array}$ & $\begin{array}{l}\mathrm{Na}_{2} \mathrm{O} \\
(\%)\end{array}$ & $\begin{array}{l}\mathrm{K}_{2} \mathrm{O} \\
(\%)\end{array}$ & $\begin{array}{l}\mathrm{TiO}_{2} \\
(\%)\end{array}$ & $\begin{array}{l}\mathrm{P}_{2} \mathrm{O}_{5} \\
(\%)\end{array}$ & $\begin{array}{l}\text { LOI } \\
(\%)\end{array}$ & $\begin{array}{l}\text { Total } \\
(\%)\end{array}$ \\
\hline HPD1109R01 & $25^{\circ} 05.581^{\prime} \mathrm{N}$ & $124^{\circ} 32.363^{\prime} \mathrm{E}$ & 1,536 & 75.25 & 12.44 & 3.17 & 0.102 & 0.12 & 2.2 & 4.61 & 1.04 & 0.164 & 0.02 & 0.98 & 100.1 \\
\hline
\end{tabular}

All elements were analyzed using fusion-inductively coupled plasma (FUS-ICP). Detection limit was less than $0.01 \%$
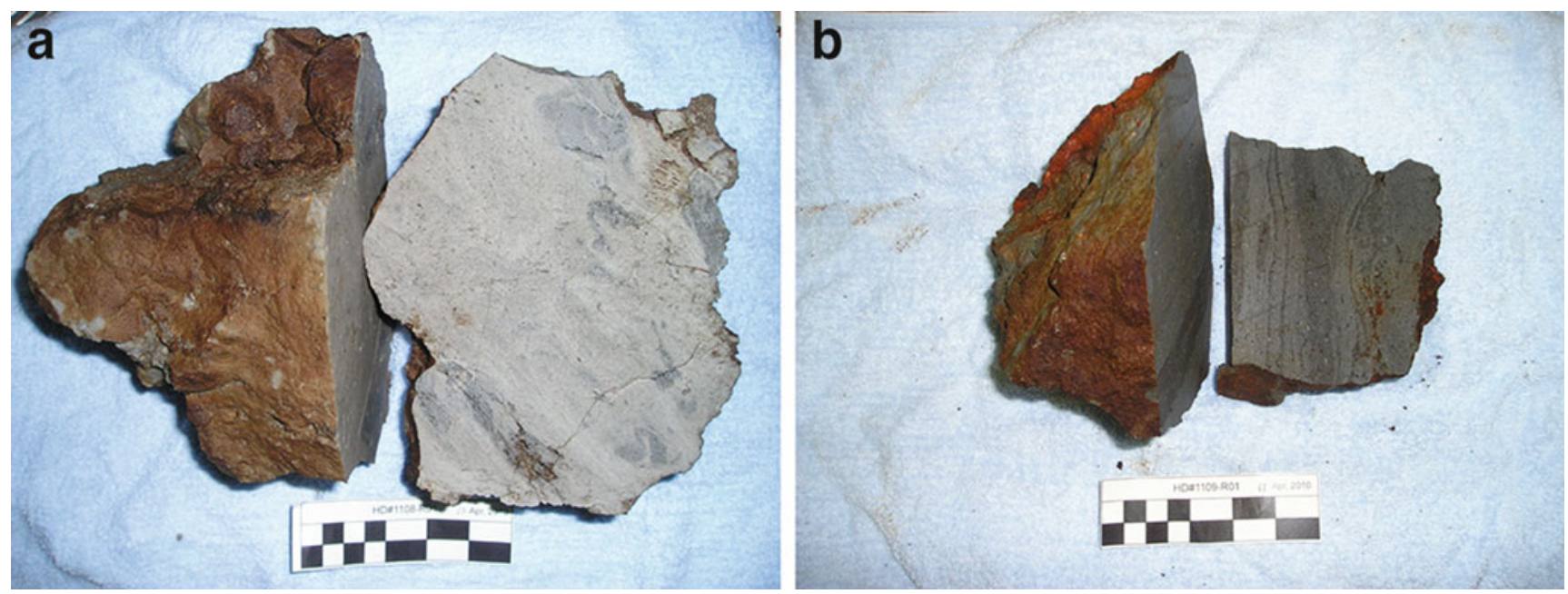

Fig. 40.6 Photographs of rock samples. (a) Pumice-like porous and whitish rock. (b) Lava fragment

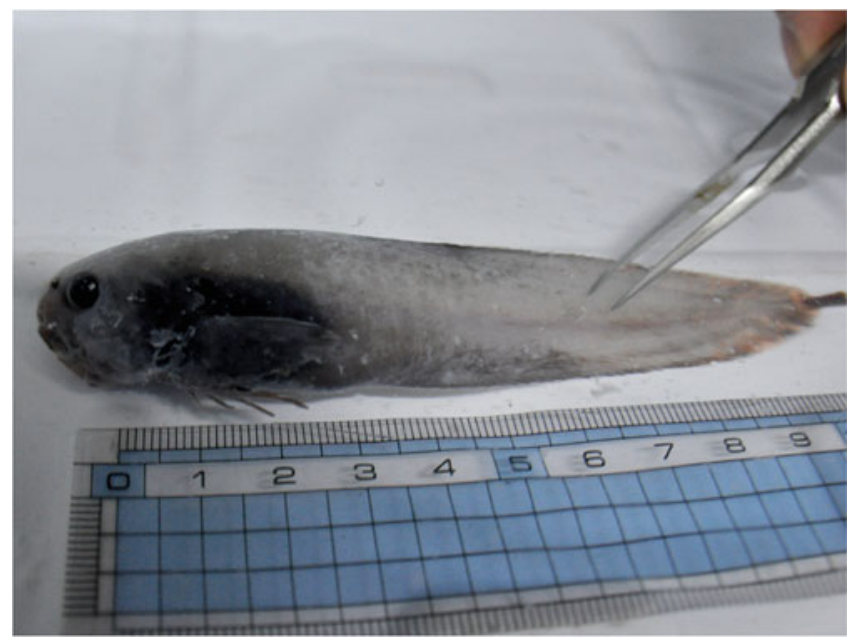

Fig. 40.7 Photograph of liparid snailfish specimen that contained Alvinocaris shrimp and shell of Provanna snail in its gut. The specimen was sampled during HyperDolphin dive \#1322 in 2011. This photograph was provided by Mr. M. Miyazaki

compounds (e.g., hydrogen sulfide), possibly of hydrothermal origin, as energy sources (Yamanaka et al., Chap. 10).

Microbial communities in turbid water (plume) were investigated and documented by Sunamura and Yanagawa
(Chap. 3). The microbial community structures based on $16 \mathrm{~S}$ rRNA genes revealed that potential thiotrophic and methanotrophic microbial phylotypes were predominant in the plume. The results were comparable to the microbial communities associated with the active hydrothermal areas in the Okinawa Trough.

The observed dense turbid water (possibly hydrothermal plume water) and biological studies suggest that active hydrothermal venting is occurring in this area, and the venting fluid is expected to contain hydrogen sulfide and venting as a black smoker.

Acknowledgements All of the fluid, water, sediment, and biological samples were obtained through cooperative efforts of the operation team of the ROV/HyperDolphin, and the captain and crew of the support ship R/V Natsushima, to whom we extend our heartfelt thanks. This research was supported by the Ministry of Education, Culture, Sports, Science and Technology of Japan through a Special Coordination Fund 'TAIGA' project (Grant-in-Aid for Scientific Research on Innovative Areas, No. 20109005).

Open Access This chapter is distributed under the terms of the Creative Commons Attribution Noncommercial License, which permits any noncommercial use, distribution, and reproduction in any medium, provided the original author(s) and source are credited. 


\section{References}

Fournier RO (1977) Chemical geothermometers and mixing models for geothermal systems. Geothermics 5:41-50

Fujikura K, Okutani T, Maruyama T (2012) Deep-sea life: biological observations using research submersibles, 2nd edn. Toukai University Press, Tokyo (in Japanese with English captions)

Ishibashi J, Urabe T (1995) Hydrothermal activity related to arc-backarc magmatism in the western Pacific. In: Taylor B (ed) Backarc basins: tectonics and magmatism. Plenum, New York, pp 451-495

Letouzey J, Kimura M (1986) The Okinawa Trough: genesis of a backarc basin developing along a continental margin. Tectonophysics 125:209-230
Miyake Y, Shiga N, Nakashima K, Kimura S (2009) Dense colony of Appendicularia (Oikopleura sp.) observed in hydrothermal plum of Okinawa Trough, Abstract of Annual joint meeting of The Benthos Society and The Plankton Society of Japan. Sendai, Japan, Oct. 16th to 18th (in Japanese)

Otani Y, Tsuchide M, Shibata A, Kato S, Iwabuchi Y (2004) The list of volcanoes and their activities records in the adjacent seas of Japan, 3rd edition. Rep Hydrogr Oceanogr Res 40:1-61 (in Japanese with English abstract and captions)

Takemura A, Tamotsu S, Miwa T, Yamamoto H (2010) Preliminary results on the reporoduction of a deep-sea snailfish Careproctus rhodomelas around the active hydrothermal vent on the Hatoma Knoll, Okinawa, Japan. J Fish Biol 77:1709-1715. doi:10.1111/j. 1095-8649.2010.02789.x 